\title{
Century of the Angklung Journey and Its Establishment in Thailand
}

\author{
Poonpit Amatyakul \\ College of Music, Mahidol University, Salaya, Nakon Prathom 73170, Thailand
}

\begin{abstract}
Both Thai and Javanese have been with lifelong cultural friendship for over 250 years. Thai people enjoyed the Panji storytelling since the late 1700's and have been using Panji as written Thai poetic literature and for court theatre over 2 centuries. We shared the same brass knobbed gong culture with its pentatonic (Slendro) and septatonic (Pelog) equidistance scales. The angklung, bamboo shaking instrument, were brought as a gift to royal children by HM King Rama the $\mathrm{V}$ to Siam since 1871 but the ensemble were not set up until our great court musician named Jangwang Sorn Silapa-banleng, took the instruments from Sunda West Java to Bangkok in 1908, later, he established the very first Thai Angklung Ensemble played several songs he composed in pentatonic scale same way he heard in the Javanese Islands. Since then, the bamboo angklung were made with the Thai native bamboo followed by the nationwide uses. This paper describes the Angklung Journey from West Java to Thailand showing the historic photographs of Thai Angklung music teachers, their houses of Angklungs and the music they composed. Today, Thai Angklung were used for children classroom music. DVD and Musical Disc of Thai Angklung will be demonstrated, bringing both music knowledge and enjoyment to show the cross cultural examples of the two nations.
\end{abstract}

Keywords: angkalung, angklung, calung, indonesia and thai cross cultural music studies

\section{INTRODUCTION}

The Sundanese Angklung, the very well-known bamboo rattle idiophone music and an ensemble of Indonesia, has been worldwide enjoyment music to all nations who heard and watched the group playing. It has been the most unique of great unity among players owned by the Indonesian Musical Culture for centuries. Since each member of the ensemble will play only one rattle bamboo frame of a single note. Then, the song melody must be sounded in a very appropriated tonal contexture with perfect rhythmic of togetherness.

Since the Java Islands located in tropical area where bamboo can grow well and widely all over the land, thus the history and development of this bamboo music must be lasted for several centuries dated back with the history of the nation. Kingdom of Siam had good relationship with Kingdom of Java by trading and cultural exchanges for over 500 years. In the late 1700's, the 
court of HM. King Baron Kote (1733-1758) of the Ayudhya, enjoyed the Panji story telling by the Javanese ladies who worked with princesses of the inner.

1) Panji's story in Siam has 2 versions, first called Dalang (Big Panji or Big Ino), second called Ino (small Panji) court.

Later years the story were written into the poetic form for singing with several Siamese traditional melodies as well as used for the Siamese court theatre, it played by female royal court dancers, called the Lakon Nai. Unfortunately in April 1767 Siam was defeated by the Burmese troops. A vigorous and extensive fire burned out lot of housing and written materials, followed with the great loss of artist lives. It took over 16 years for the recovery.

It was HM. King Rama I (1782-1809) who had renewed the composition of the Dalang in form of a literature book and for the court plays, but it was not popular. The Story of Panji then re-written again by King Rama II (1810-1825) for court theater during with great success with the new name Ino (e-naw). The story and plays were very well-known and loved by the Thai for over 100 years. Now Thailand owned several versions of the Panji books.

2) There are 5-6 versions of Panji story books in Thailand today.

There are two play-writings by King Rama I and Rama II, one drama writing by Rama V, and two more books were the translation into Thai language by HRH Prince Paribatra (1940) and the other Thai plays named Panji Semirang by HSH Princess Chalerm Ket Mongol (1950). We can say that the Panji story and tales has made Thai and Java in a close relationship for over 250 years.

About the Sundanese Bamboo Angklung, the story started in 1870 at time of the first visit of HM King Chulalongkorn or Rama the $\mathrm{V}$ to the city of Batavia (Jakarta). The king, at the age 17, enjoyed the local Javanese music receptions which showed several types of the gamelan music as well as the amazing bamboo angklung group. This bamboo set of instrument, played the traditional Javanese and the short European pop songs using two different musical scales.

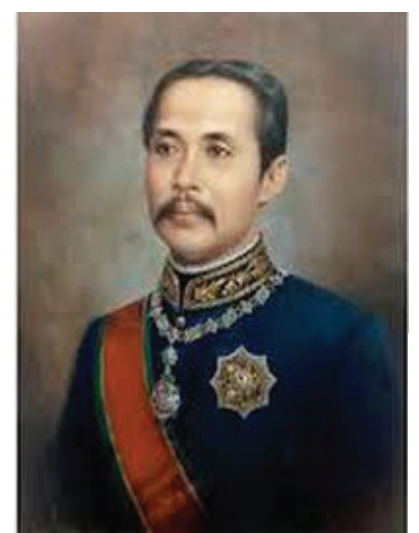

HM King Chulalongkorn of Siam (1853-1910) had made 3 visits to Indonesia 1870, 1896, and 1901 on the second visit the set of 8 Javanese Angklung frames were bought and use as music toys for his royal children. 


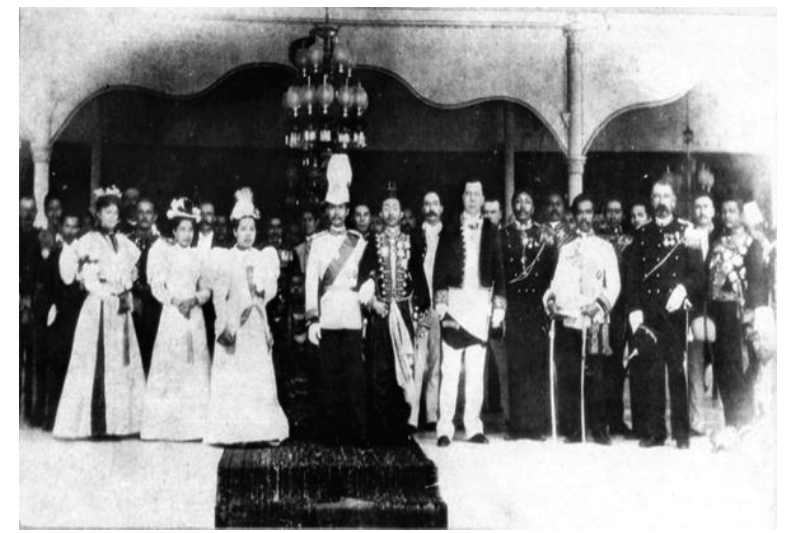

1896 Rama V \& Queen Sawapa of Siam visit to the Palace of King Susuhunan of Surakata

In 1896 King Rama the V again had a re-visiting to the middle Java area. There were several towns and royal residences he visits within this trip, such as the town Karoot, Surakarta, Yogyakarta, and Bandung. Later, we learned from the king's visiting report printed in 1972 (3) that: On June the $10^{\text {th }} 1896$, at the town Karoot, he watched a Sundanese Angklung played with the 5 tones of the rattle Angklung frames. Each frame had two bamboo tubes rattling with a single note. The beautiful sound came from a group of players. The King brought the Angklung instrument back to his palace in Bangkok that year. They were placed in the children's room at the inner court pavilion.

3) King Rama $5^{\text {th }} \mathrm{s}$ written report of his second visit to Java Islands on 1896 was published in $1972,2^{\text {nd }}$ edition.

HRH. Princess Hemavadi (1892-1971) the king's youngest daughter told the writer that, she and her older siblings enjoyed those Angklung for many years, unfortunately there was no one in the court could direct the royal children to played those Angklung within the proper music way. Later in the year 1908, the younger brother of King Rama V, named HRH Somdet Krom-pra-ya BhanuRangsri-Sawangwong (1859-1828), had visit to Yogyakarta, Semarang, Bandung, etc.

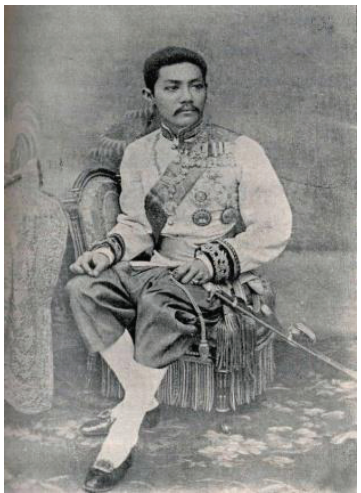

HRH Prince Bhano-Rangsri

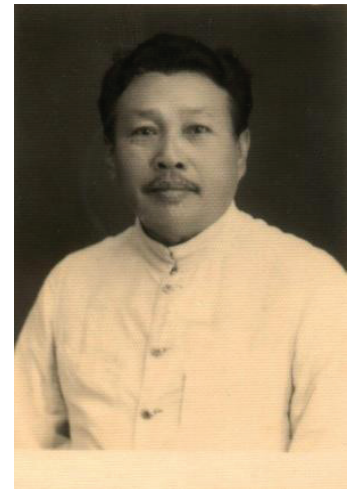

Jawang Sorn Silapa-Bunleng 
The prince brought with him his young musician named, Jangwang Sorn Silapa-bunleng (1887-1954), that time the young man was only 27 years old but happened to be much interested in the Sundanese Angklung. He brought a set of 10 Angklung frames back to Siam and they were sounded for the first time in Siam at the Burapa Palace in Bangkok. That time Jawang Sorn used the 5 tones scale (slendro or pentatonic mode) with his several new songs he composed to the public. Thus the original Javanese Angklung started its function here in Siam since the late 1908. Those songs he composed were among the New Javanese Overture (โหมโรงยะวาใหม), Semarang (สะมารง), Kadeeree (กะดร), Bukan-tumoh ([บกน ตูโมะ), etc. All of them are still used in Thailand till to day.

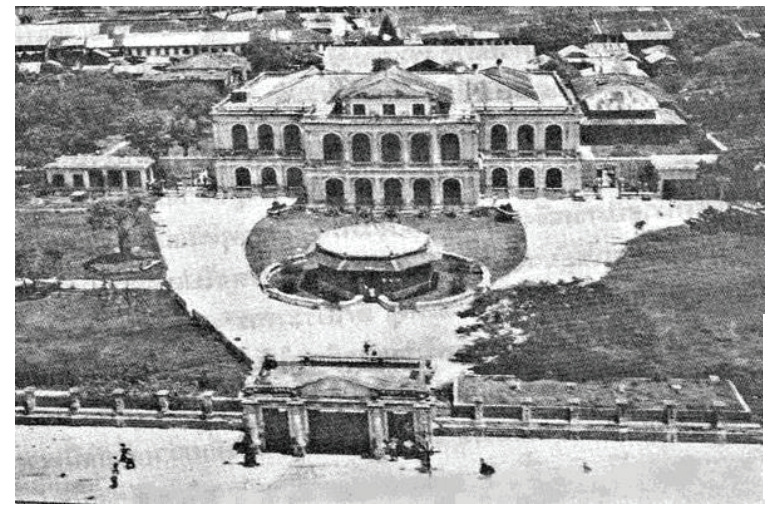

The late Burapa Palace in Bangkok where the Angklung music was first performed in 1908 by Jangwang Sorn Silapa-Bunleng

Siam is also the country of tropical zone and we owned lot of bamboo but not the same species that are grown in Java. Our bamboo are rather thick and heavier than the originals. Jawang Sorn then ordered his man named Mr. Choom (นายชม) to make the Thai Angklung but they were rather heavy in weight. Many Thai traditional music houses tried to make their own Angklung ensembles. There were several outstanding houses belonged to Mr. Earn Dischey (เอน ดฐเชย) and Mr. Mo (ลงโม) who made the ankung same style like the Sundanese with 2 bamboo tubes in one frame. Since the Thai traditional music can be both in 5 and 7 tone scales (same as the Javanese Slendro and Pelog scale). It was Mr. Keang (นายเคยง) who made the first 7 tones Thai Angklung set since the late 1924's. It was the first time to play the Angklung with old Thai traditional songs.

Later, they found bamboo forest near the Prachinburi Province, East of Bangkok where lot of light weight bamboo tube were grown there. Finally the bamboo plant was brought and planted in Nonthaburi, the nearby city to Bangkok. Thus the Thai Angklung houses were established close to Bangkok especially in Nonthaburi province. Those houses belonged to several master of Thai music such as Mr. Plung Premjai (ครปลง เปรมใจ นนทบุร). Who was pioneer making the Thai Angklung with form of three bamboo tubes in one frame. They changed the way 
of sounding technique from rattling to the one hands shaking with one frame. Thus the Thai playing style was changed from rattling to the shaking and they used 2 frames at a time, thus one player can shake 2 frames with 2 notes, each on one hand.

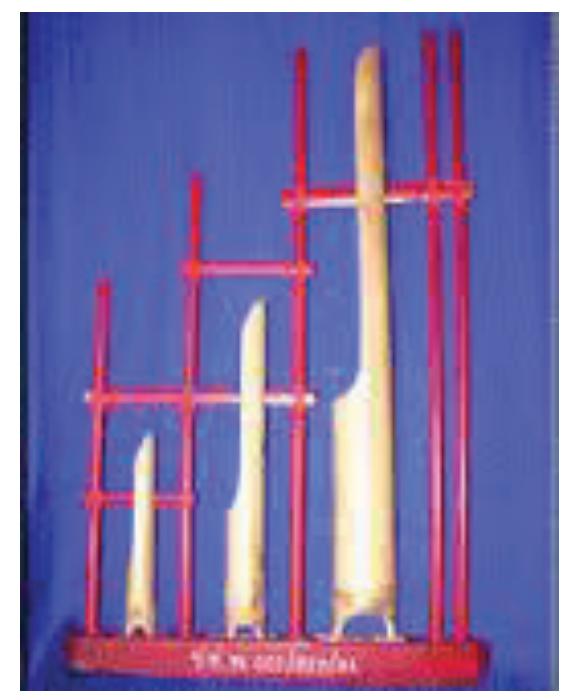

Thai Angklung with 3 tubes played by one hand shaking

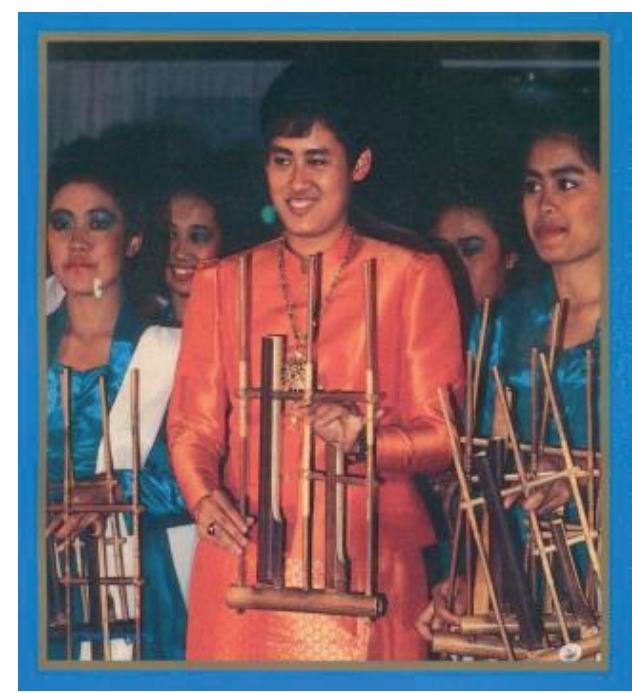

HRH Princess Sirindhorn used 2 tubes Javanese Angklung, 1984

Before the second world war, Thai Angklung were very well used in local school children as music in classroom. This was quite good for unity practicing of group music and as well as its price was not that high. A Thai Angklung set of 10 to 14 frames cost only 200-300 Baht. Today, music education in school class for outdoor were very common with the larger Angklung ensembles. Sometime they used over 100 students.

After the second world war, western popular music have been well loved by the young people, then the Thai Angklung were made in chromatic scale and they were used separately from the old set played with the original Thai traditional tone scale. The Royal Thai Military music department organized the big military Angklung ensemble of 30-40 player conducted by Captain Sanom Noileck. They played both Thai traditional and pop songs with the western music arranging techniques of which it resulted in the most beautiful concert ever done in Thailand.

In music recording business, there were several Thai pop recordings made by Mr. Saman Kanjana-palin with the contemporary music mixing the Thai Angklung played alomg with the jazz big band.

Nowaday, musicians who play Thai Angklung also use the music notation. It can be the general western note or Thai note as shown below. 


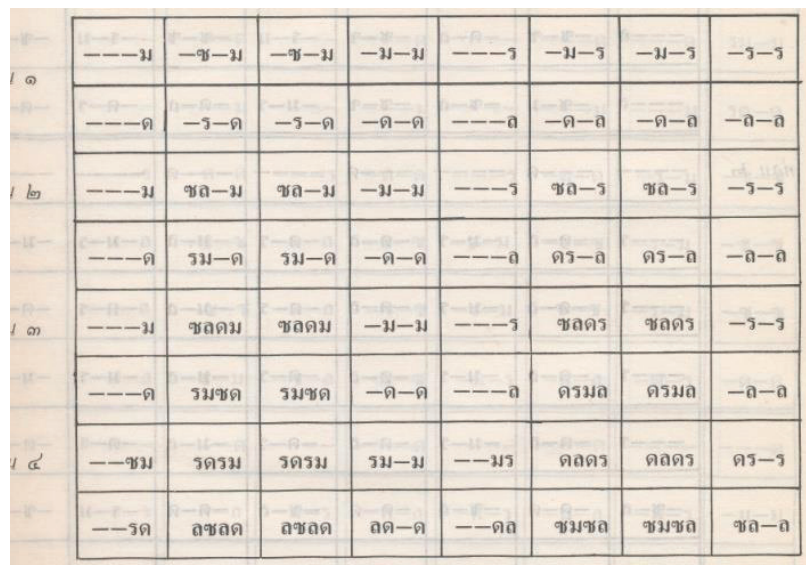

Jawang Sorn's Thai Notation for the Javanese melody of a song named The Buiten-zorg, A 5 note slendron scale.

There have been lot of Thai traditional music teachers who teach and made Thai Angklung for living. They all used their home as a small factory and made Angklung by hand. Several have passed away such as Mr. Sakol Kaew-Pengard, Mr.Chalerm Bua Thang, Mrs. Angoon Bua-Eaim, and Mr. Nam Poom-Yu. One of the best known teacher that should be mentioned was Mr. Phol Kit-Khan of the Nonthaburi Province. The family of Mr. Phol was a Durian Fruit Gardener who made lot of money each year selling the durian fruit. He also owned the Thai traditional music ensembles, the angklung ensemble and the western brass band. He has been the outstanding music teacher of the middle school. He had the light weight bamboo plant that was quite difficult to find. His profession was to make Angklung for school children so he decided to cut all of the good durian tree and replace them with the bamboo plants.

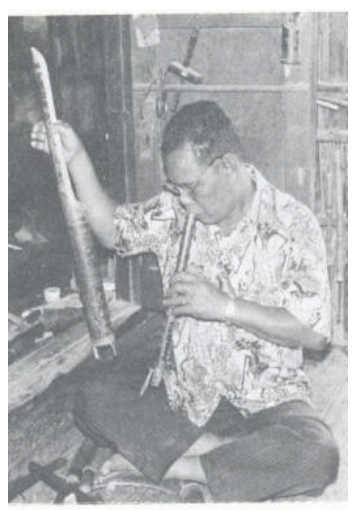

Mr.Phol Kitkhan

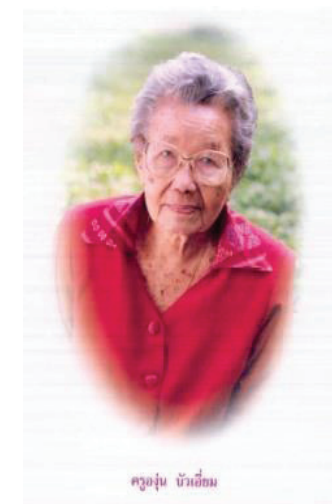

Mrs. Agnoon Bua-eam

Outstanding Angklung teachers and Home factory owner 
At present, the Thai Angklung are made in the medium size home factory founded in middle Thailand and they made a large frame of 10-18 hanging Angklung frames that is able to play by one man alone.
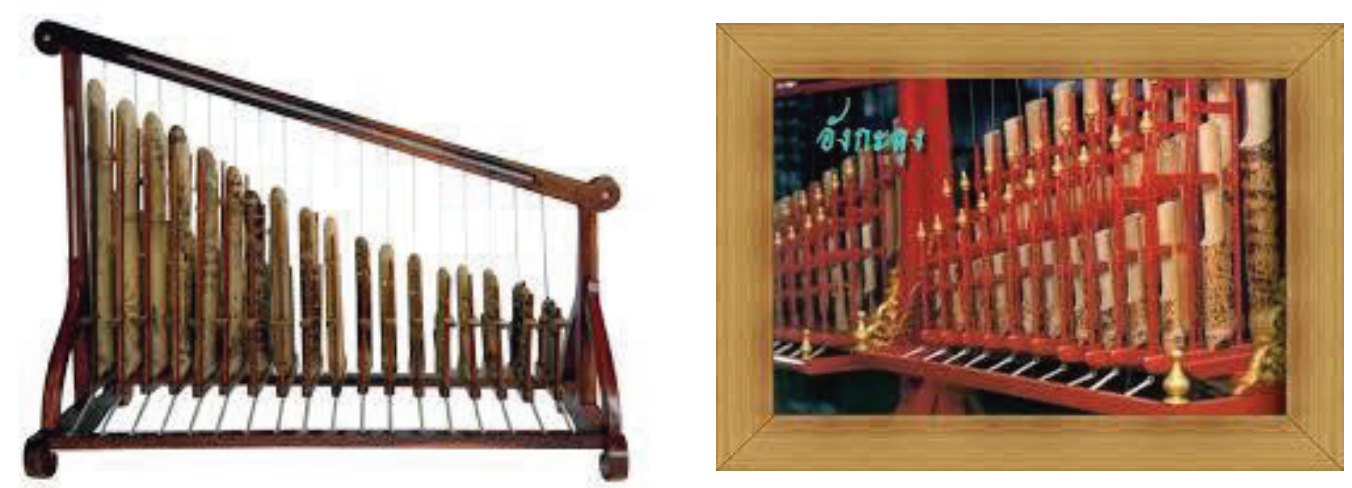

Setting of 18 hanging Angklung for one player

However this setting was not commonly used in school music class but were used at time of music recording since it is easily and well controlled by a single player himself.

We must thank the original Javanese Angklung that came to Thailand. They have been very useful, very good and very productive instruments for unity training of players and no matter they are young or old. Moreover, they sound very beautiful by the nature of the bamboo themselves. The most important thing that one should remember when using the Angklung is the original and traditional music scales of its ethnic origins. We should be very truly faithful to the national and natural musical modes of such an instrument and always.
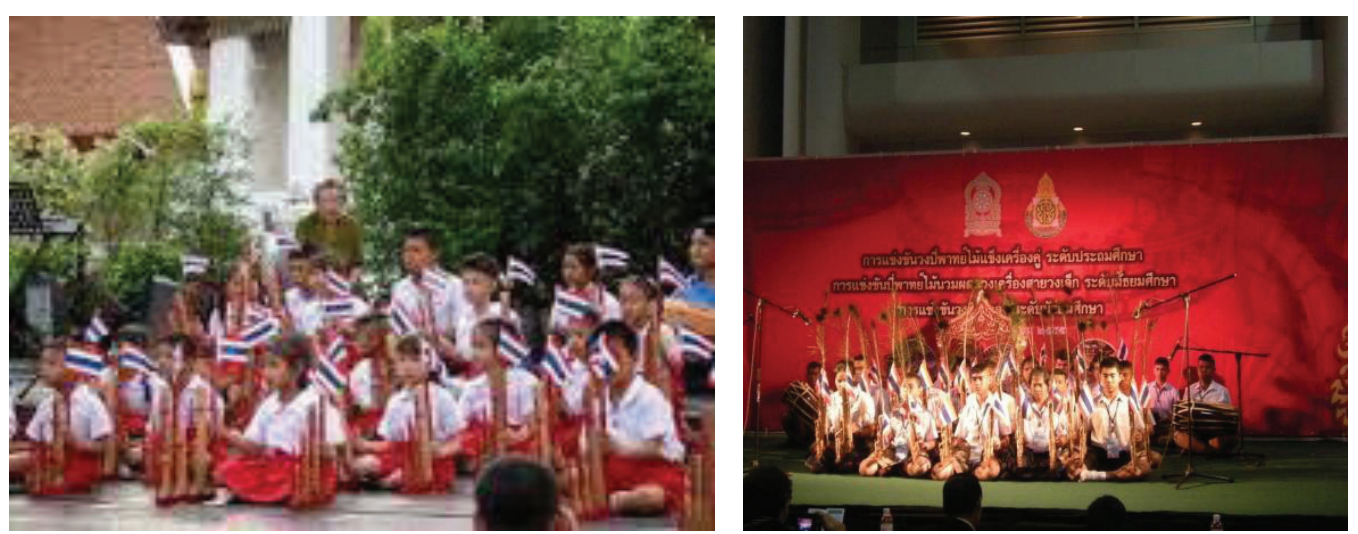

Kinderkarten Angklung Ensemble, Thailand See 3 teachers in closed watching with hearted care. 
According to the large size bamboo Angklung instruments, it should be stated that Thailand never own the big bamboo idiophone which is bigger than the ranad thum xylophone we commonly used in the pipat ensemble. We are not lucky to own such a large size bamboo for making musical instruments like the country of Indonesia.

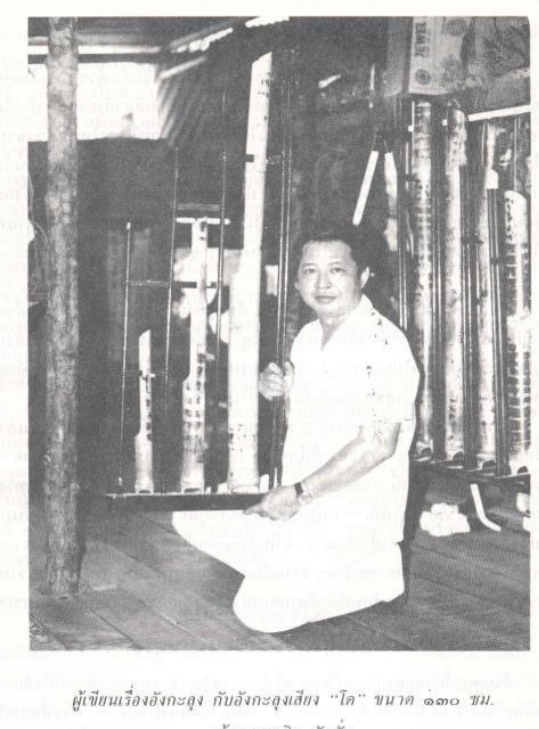

ข้านครูเจลิม บัวทั่ง
Writer with Thai Angklung $150 \mathrm{~cm}$ high

Finally it may say that the journey of Javanese Angklung since the past century has become the permanent music style of Thailand and they will last as long as the bamboo plants are still well grown in this area of the world.

\section{REFERENCES}

Amatyakul, P. 1985. Thai Angklung, History, Tale, Notes, Home factory and 58 school training songs.

Chalam Ms. 1984. Story Telling, Tale of Angklung.

HM Rama V. 1972. His records on the 2 months visit to Indonesia in 1896. Printed in Thai. 